\title{
UPON PARASITIC FUNGI.
}

\section{BY T. J. BURRILL,}

\section{(Professor of Botany and Horticulture in the Illinois Industrial University.)}

Many doubt the action of microscopic fungi in causing diseases of higher plants and animals. Indeed it has only been in our century, and mostly in the latter part of it, that botanists have distinguished these minute parasites as independent plants. Schleiden (1) in a work written about 1845 said, "I cannot regard the true Uredines, etc., (Coniomycetes) as independent plants. Meyen (2) observed the formation of Urerto maidis as an abnormal process of cell formation in the interior of the cells of the parent plant; and, in this respect, my own observations on Elymus arenarius coincide with his." Unger (3) in 1833 sought to prove that the so-called fungi were changed conditions of diseased tissues; and Fries in a classic work upon fungi, holds similar views.

But the matter is not left undecided The improvenents in microscopes, and in methods of tracing the life history of low organisms, have forever settled the doubte in the minds of scientific men. Nothing ean be more satisfactory in the way of evidence, than to see with one's own eyes the spores germinating, penetrating the plant tissues, and in due time producing again spores like the , riginal ones. This has been done again and again, and may be seen by any one who will take the trouble to follow, day by day, the development of any of the hundreds always and everywhere at hand. Their

1. Principles of Scientific Botany. London, 1849, p. 151.

2. Ueber die Entwickelung des Getreidebrandes in der Mais-Pflanzen, Weigmans Archiev., 1837, p. 419.

3. Die Exantheme des Pflanzen, Wein, 1833, p. 356. 
effects, likewise, may thus be observed, obliging the most skeptical to admit the ageney of the parasites in causing the malady to which attention is given.

Probably Prevost first discovered the fact, that the spores of fungi germinate. This was in the first decade of our century. Since then many eminent naturalists have given abundant testimony as to the true parasitism of species, and of their individuality as such. We may, without disparagment to others, mention the names of Leville (4), Tulasne (5), Berkeley (6), and M. Bary (7) as authorities, whose writings have conclusively established the fact that these parasites do cause the maladies attributed to them. Robin (8) and Leidy (9) have published prominent treaties on the vegetable parasites upon living animals.

Observers in this field are now much more numerous than ever before and, having the advantage of the former contributions, are gaining rapidly in the knowledge of kinds and of the injuries caused by these small but in no wise insignificant organisms. Preventives and cures naturally follow investigations of cause. They certainly cannot precede the latter except by accident; hence, if any one feels like asking "What use?" let him possess himself in patience;-in the coming time, man will assert his dominion here as well as elsewhere over the natural world. Something has already been done. The vine disease in Europe has been kept down by the use of sulphur, as are the rose and verbena mildews in green-houses. Sometimes prevention is attained by removing promptly attacked parts, as in the case of the peach-rot, and, as further detailed below, sometimes by destroying the spores of the fungus, as in the bunt of wheat. Cultivators now often unconsciously scatter the germs and ignorantly provide ways and means for their development. The march or migration of a parasite of this kind is sometimes as well marked as that of an injurious species of insect.

Puccinia malvacearum, Mont., affecting eultivated hollyhocks, has been traced from South America through the United States to England and thence to the continent as certainly as the Colorado potato beetle has aeross our territory. Timely, intelligent action in sueh cases might avert great disaster. Had this fungus attacked the cotton plant, as it was feared it would, what estimate could be placed upon the loss! What money-value is destroyed in our own state by rust (Pucciniugraminis, Pers.) on wheat, oats, ete.; what discoulaging losses by the multitudinous blights upon our cultivated crops, many of which are known, and others supposed to be, caused by parasitic fungi!

4. Annales des Sc. Naturelles. 1839, etc.; and "Mycologie," and "Uredines," in Dict. d'Hist. Nat., par D'Orbigny.

5. Amales des Sc. Naturelles, 3 ser., tome VII, 1847 : 4 ser., tome II, 18.44.

6. Introduction to Cryptogamic Botany, London, 18;, p. 261. Outlines of British Fungology, London, 1860, p. 68.

7. Ueber der Brandpilze, 1853. Horphologie und Physiologie der Pilze, 1866. and many papers in Annales des Seiences Naturelles and elsewhere.

8. Historie Naturelle des Vegetaux Parasites qui croissent sur l'homme et sur les animaux vivants, par Charles Robin, Paris, 1853.

9. A Flora and Fauna Within Living Animals, by Joseph Leidy, Snithsonian Cont. to Knowl., Vol. 5, 1853. 
Aside from what may be called the practical value of the study, including that which leads to the better understanding of the higher forms of living things, these microscopic creations have many attractions for the student. Nature is always, and to every one, interesting; her pursuit is alluring in the highest degree. To see rare forms men traverse oceans and make pilgrimages over continents; but here are countless unseen living things, under our feet, on every side, in the air we breathe, in the food we eat, on plants, on animals, germinating and propagating under our own finger nails and even in our mouths, possessing a variety of form and structure, often curious and beautiful, never equalled by art and not surpassed in nature. Their wonderful life-histories stimulate inquiry, engage and enchain the attention. He who possesses a microscope, with the ability and opportunity to use it, need never wander from his own door to find an abundance of material awaiting his researches, and entertaining and instructive biographies ready for bis pursuit. (10.)

The Peronosporie. (11). Among the pests to the cultivators of fields and gardens, the members of this family maintain a bad pre-eminence. None have attracted more attention from the injuries they do to important plants, and from their peculiar and interesting life-history. Formerly classed in widely different groups on account of their difference in structure, the species have been united from their agreement in development. All produce conidia,-naked spores borne upon the tips of erect filaments or hyphx, - which in some cases germinate directly and sometimes give origin to some balf-dozen zoospores. The latter are small, more or less globular bodies, capable of rapid movements in water by means of two long cilia, which they lash from side to side with astonishing rapidity. They thus swim in a drop of rain or dew some minutes or hours; then, losing the propelling hairs, settle down, and under favorable circumstances germinate like the conidia by protruding one or more slender tubes, which penetrate the tissues of the supporting plant and become the mycelium or vegetative threads of the fungus. Besides, through the conidia and their offspring, the zoospores, these particular plants have another method of reproduction. The term oospore has been given to a fruit-body found to arise from the conjoined action of two separate cells of the mycelium. This is a sexual process well known among the algæ or sea-weeds, but not yet well made out in most fungi, and analogous to the production of seed in flowering plants by the united action of stamen and pistil. The cell producing the oospore is called a gonosphere or oogonium, and its partner an antheridium. The oospores are found on or in the tissues of the host, sometimes only upon one of several plants that the conidia are found upon. Unlike the latter, they lie dormant for some months, but, like them, finally give origin to

10. Cooke's little book on Rust, Smut, Mildew and Mould is an excellent one for a beginner.

11. The plants enumerated in this paper are from collections made by the author between September 21st and and October 16th, 1876. mostly from the area of ground upon which he makes his home. Any collector will perceive that more of the Uredines and other families are omitted than are mentioned. 
zoospores which appear identical with those produced by the conidia. The office of the oospore appcars to be to pass the winter. The family consists of two genera, Peronospore and Cystopus. The species of the former have the appearauce of moulds, producing conidia singly or in clusters at the tips of the fertile threads, while those of the latter occur as white pustules on leaves, bearing the conidia in moniliform strings, the fertile hyphae or threads having no promineuce. Generally the myeelium of both has curious processes, termed hauptoria, penetrating the cells of the supporting plant, as shown in Plate II, Fig 7. The threads themselves, when first emitted from the spore as well as when buried and ramified in the tissues, often penctrate the cell through and through, being found at considerable distances from the diseased-looking spots upon which the fruiting threads appear.

Over forty species of Peronospora have been described, of which only six are known to exist in the United States. Many others probably await the researches of botanists. Of the six, three, by far the most common ones, are in the present described collection.

Peronospora infestans, Mont., (Plate II, Fig. 8.) Very common on potatoes and tomatoes. It has also been found on Bittersweet (Solanum dulcumara), and even upon a not closely related plant, Anthoceris viscosa (12) belonging to the Scrophulariucer. This is by far the most famous, or infamous, of the species of this genus, causing the well known and often dreaded potato rot. Its history has been often told(1;), but a new chapter was added last year by Worthington G. Smith (14), of England. Previously the oospores had not been found as such, and so much search had beeu made for them that it was quite generally believed that they must exist upon some other supporting plant. Clover, among others, was suspected. 'The finding of them in the tissues of the leaves and stalks of the potato settled the doubt and bids growers beware of leaving the old potato top to breed the pestilence another year.

P. gangliformis, Berk, (Plate II, Fig. 3.) Common on lettuce and some allied composita (Lactuca altissima and Nabalis allus. Farlow.) '/oospores not observed. Conidia germinating and penetrating young leaves, the tissues usually decaying from above dowuward until the whole plant is involved and becomes a slushy, putreseent mass. This parasite is especially destructive in forcing-houses. Several hundred dollars worth of lettuce was lost by one propagator here last winter from this fungus (15). The only cure now known is to keep the atmosphere as dry as practicable and remove very earefully the diseased leaves.

P. viticolu, B. \& C. (Plate II., Figs. 6 \& 7.) Common on grape leaves, and becoming very destructive in this vicinity, worse apparently

12. Farlow, Synopsis of the Peronosporeae of the United States, Bulletin of the Bussey Institution, p. 426.

13. Smith, Ohio Ag. Report, 1872, Essays, etc., p. 20.

14. Farlow, Gardener's Monthly, Nov. 1875, p.274. Smith, Ohio Ag. Report, 1862, Essays, etc., p 20.

15. Smith. Gardener's Chronicle, July 17, 1875, p. 69. Quarterly Journal of Microscopie Science, October, 1875 . p. 415 .

16. Farlow on the American Grape Vine Disease. Bulletin Bussey Institution, 
upon the smooth-leaf varieties. The Clintons were nearly or quite killed by it the last two summers. This seems to be a native American, and has often been mistaken for Erysiphe tuckeri, Berk, which constitutes the vine disease in Europe, - a mistake which has led to an error and disappointmeut in its treatment. Sulphur proves effectual in case of the Ery.iphe, but it lives upon the surface of the leaf, not in the tissues, as does our plant. Notwithstanding the continued failures, cultivators still are known who spend their time and money with the sulphur remedy, showing again the importance of the knowledge of the species and their habits. But, unfortunately, a practicable remedy is not now known. The condia produce zoospores, which swim in water some fifteen minutes, then germinate. The oospores are found among the cells of the leaf in autumn. If all the old diseased leaves could be burner, a preventive would be attained.

During the last winter (1874-5) a parasite (Plate I, Figs. 5, 6, 7, 8, 9, $1 n, 11)$ was noticed upon many of the plants in the green-house belonging 1.. the Illinois Industrial University. A few of the diseased leaves being taken home for examination, although they were exposed but a few minutes in a room with previously healthy window plants, the same disease soon appeared upon the latter;-a case of the unwitting distribution of disease germs by man. Our real study of this species commenced, however, in October, 1876, when it reappeared in both the localities just named. In one case a box of earth in which some affected plants grew last year (winter of '75-6) was left dry during the summer and some healthy plants replaced in the box in October, 1876. Every care practicable was taken to see that these plants were sound and to exclude infection from any other source. In a week's time there was evidence in abundance of the same parasite. The conidia are now known to germinate when at least one month old, but did they lie dormant all summer? Supposed oospores were found in the petals of Salvias, and figured (Plate I. Fig. 10.) This body is 1-500 in. in diameter, with an apparent hyaline reticulated epispore and a yellowish included spheroid. The fertile hyphæ are dingy or smoky colored, torulose when dry, septate, simple or branched, bearing conidia in dense clusters on the sides and tips of the rigid, blunt extremities. Conidia oval, pappillate, slightly tinted, 1-1800 by 1-2660 in. Believing the plant to be an undescribed Peronospora, it was christened $P$. fumosa ; but later examination, sinee the figure was made, makes it questionable about the so-called oospore being such. If not, the plant may belong to the aforetime related genus Poltactis, Link, in which case its parasitism on living plants is an anomaly. The conidia germinate in water, often emiting two or three tubes. Zoospores not seen. On the leaf the germinating tubes run over the surface or penetrate through the cells to the interior. In about five days from the sowing, the fertile hyphæ appear with their conidia. They arise from the stomata or from the external mycelium. Sometimes the conidial hyphre do not appear until the leaf or young stem is in an advanced state of decay. On some plants only unhealthy or fallen leares appear to be affected. Salvias, Geraniums, Centaureas, Senecios and others of diverse orders suffer from its attacks, while as many as twenty kinds have been found living or dead with the fungus upon them. Had time 
permitted, I should have been glad to submit this plant to the inspection of others before, perhaps, thus exposiug my own incapacity. The only similar figure which I have seen is in Schleiden's Principles of Scientific Botany, London, 1849, Plate 2, Fig. 8. This cannot be the plant.

Of the four recorded United States species of Cystopus, three werc found. These are exceedingly common on the plants indicated. They do not, howerer, have the blighting effect of the Peronosporio. Plants thoroughly dotted with their pustules appeared to survire without great injury. Their microscopic character is so well known to botanists that nothing would have been gained by selecting new specimens to figure, so in my haste copies were selected as indicated. The other figures are from the collection, but none of the plants are more common than these.

Cystopus candidus, Lev., (Plate I, Figs. 1, 2, 3, 4.) Common on cruciferous plants, notably here on horse radish and cabbage.

C. cubicus, Mart. On Ambrosia artemisixfolin, the common rag weed.

C. bliti, Bivon. On Portulaca oleracea (purslane) and Amaranthus retroflexus.

Perisporiacei. Notwithstanding the similarity of the names of these families, the plants are very different, as a glance at the plates will show. They, however, agree in their injuries to living plants, constituting very many of the leaf blights of this and other countries. Some of them are most exquisitely beautiful under the magnifier, a thing which the disciples of the derelopment theory of species have not yet accounted for. Their beauty surely does not come from natural or sexual selection. The mycelium runs over the surface of the leaves, never appearing to enter the cellular structure, yet, in some way, deriving nourishment from it. Here applications, as of sulphur, bare direct effect. Here, too, the vine and the hop mildews belong. Conidia are borne in moniliform strings arising from the mycelium. The two together often give the affected leaves a dusty, whitened appearance, as if eoated with whitesash. Later the spherical bodies-conceptacles-of dark color, as represented in the plates, are formed, sometimes exceedingly numerous, sometimes few and hard to find. The conceptacles have not yet been discorered in the vine disease of Europe. These conceptacles have at length radiating appendages, different from the mycelium, of many different forms, though constant within narrow limits in a given species. Inside the usually reticulated conceptacles there are attached to the base one or more sporangia or spore-sacks. These are thin and transparent, showing plainly the few or many spores. Sometimes, instead of sporangia, multitudes of naked and smaller spore-like forms are found; and sometimes similar ones are contained in a stalked flask-shaped or urn-shaped ressel, as seen in Plate III, Fig. 7. Still other apparent fruit-bodies are found on the mycelium or the appendages of the conceptacles. I do not remember seeing these described, but have often met them and am fully convineed that they belong to the same plants. They are darkcolored like the Dematiei species, and of the forms shown in Plate III, Figs. $2 \mathrm{~b}, 2 \mathrm{c}, 2 \mathrm{~d}, 7 \mathrm{f}$, and Plate IV, Fig. 12. Sare in quantity, they are not unlike forms of the black mildews found on thick-leared plants and known 
under the names Fumago, Antrnnaria, Capnodium, etc., but their positive connection with these plants, positive at least in the case of the specimen figured in Plate III, Fig 2, of course destroys any sort of specific individuality. I cannot suy that they are reproductive bodies, but they certainly look like it. Other plants not distantly related have such forms of fruit. It is probable that the conceptacle, with its contained sporangia, in all these plants, is the result of a peculiar union of specialized cells (17), as in the Perono:porize.

Sphimrothecn castagnei, Lev. On Taraxicum, Hop, Spirea, etc. To this species we refer with doubt the plant figured on Plate III, Fig 3, found on Erechtites hieracifolius, but the conceptacle is larger (1-245 in.) and the mycelium denser than in any undoubted plants of the species noticed, and the appendages somewhat different. Instead, too, of being distributed over the plant, this is found almost entirely upon the stems and : inder sides of the leaves, in patches. Appendages (of which there are one to three) colored to a septum. Sporangium one, spores eight, oval, 1-8000 by $1-4300 \mathrm{in}$.

Phyllactinin guttata, Lev., (Plate IV, Fig. 6.) Common on Fraximus vividis. This species is reported to be common on Quercus, Carpinus, Berberis, Alnus, Corylus, etc.

Podosphora linnzei (?), Lev. (Plate III, Fig. 2.) On cultivated cherry. This is almost surely not kunzei, Lev., but it is the nearest to it of any I know and I am loth to call it new, since so conspicuous and injurious a species could hardly have escaped attention. Leaves of all varieties of cultivated cherries were distorted and caused to fall, from the middle of the summer until autumn. My notes are as follows: Mycelium thin, evanescent: appendages about twelve, colored at base, sometimes septate, simple or but little dichotomously forked; conceptacle black, 1-300 in., gregarious on the upper side of leaves. Sporangium eight-spored. The spore-like forms on the appendages have already been referred to. These were by no means on all the plants, but occurred on this one as shown.

Microsphxria extensa, C.\& P., (Plate IV,Fig. 2.) On Quercus rubra and $Q$. palustris in woods. The upper sides of the leaves are conspicuously whitened.

M. friesii, Lev. Very common on Syringa vulgaris. The conceptacles are sometimes abundant, but not always. The divided and curled tips of the appendages are very beautiful in perfect specimens.

M. ravenelii, Berli., (Plate IV, Figs. 7 to 11.) On Gleditchia triacanthos. This is certainly the same as my specimen in Ravenel's exsiccati, but the mycelium is much more dense. In this respect it surpasses all I have seen. The leaves are very white.

M. elevata, n. sp., (Plate II, Fig. 4.) Upper sides of leares of $C a$ talpa lignonioides. Mycelium thin, web-like, rather evanescent. Conceptacles 1-250 in., conspicuousiy reticulated, raised from the leaf; appendages about twelve, colored at base, often simple, sometimes branched near the base, usually 2 to 4 times dichotomously forked, very long; sporangia four,

17. Sachs' Text Book of Botany, English Ed., 1875, p. 256. 
oval, strongly rostrate. This appears to be so distinct from any description giren that 1 hare named it as new. Not uncommon.

Erysiph", - (Plate Ir, Fig. 1.) On Aster puniceus. One conceptacle alone found.

E. lamiprocirpa, Lrv. On Phlox (Old Maid's Pink.)

E. murtii, Lh. Very common on leares and stems of peas. The cultiration of garden peas in late summer and autumn is precluded from the effects of this fungus as much as from the reeril which infests them. where.

Erotium herbariorum, $L k$. On plants in cabinet. Common erery-

These are all that were found in these two families, except one of the latter on leares of Liriodendron tulipifern, whi h was not matured enough to determine. Botryopinm pulchrum should not have been giren among the parasitic plants, as it is only found on decaying herbage. The figure is more slender and the branches longer than Cooke's figure. The species may not be correct. Fear of occupying too much space causes the omission of further notes. 
23, 26, 27, 31, Canthocamptus illinoisensis, Forbes

23. One of 5 th pair of legs of female.

26. One of anterior maxillipeds, $\times 250$.

27. One of $3 \mathrm{~d}$ pair of legs of male.

31. One of posterior maxillipeds.

24, 28, 29, 30, Diaptomus sanguineus, Forbes.

24. One of posterior maxillipeds.

28. One of anterior maxillipeds, $\times 66$.

29. 5th pair of legs of male.

29a. Tip of inner ramus of left leg.

30. One of 5th pair of legs of female.

\section{PARASITIC FUNGI.}

PLATE I.

1, 2, 3 \& 4, Cystopus candidus, Lev.

1. Portion of cabbage leaf with spots and holes caused by fungus.

2. Conidia, magnified 360 diam. After Cooke.

3a. Oogonium; 3b, antheridium; 3c, oospore, magnified 400 diam.

4. Oospore (the developed oosphere) ruptured, exhibiting zoospores, magnified 400 diameters. After De Barry.

4a. Free zoospores from oospore. $3 \& 4$ after De Barry.

5, 6, 7, 8, 9, 10 \& 11, Undetermined Parcisite on Green-house Plants.

5. Portion of petiole of geranium, with fungus; natural size.

6. Fertile hyphæ and conidia, magnified about 175 diam.

7. Conidium magnified 650 diam

8. Conidium twelve hours after sowing in water, outer coat ruptured and the inner protruding in the form of a tube, magnified 320 diam

9. Same conidium, thirty hours after sowing, magnified 325 diam.; germinating tube issuing from two points.

10. Supposed oospore, see text) magnified 390 diam.

11. Longitudinal section of stem of Achyranthus, with mycelium, especially following the vascular bundles, a. Also seen penetrating cells of pith, c.

\section{PLATE II.}

1. Melanispora populina, Lev. a, Portion of leaf of Populus monilifera, natural size; b, Summer spores.

2. Botryopium pulchrum (?) Corda. Magnified about 75 diam. 
3. Peronospora gangliformis, Berk. Lettuce mould.

4. Microsphæria elevata, n. sp. On leaves of Catalpa bignonioides; mag-

5. Sporangia of same. nified 75 diam.

6. Peronospora viticola, B. \& C. On grape leaves.

7. Mycelium of same, with haustoria in pith of young stem.; magnified 350 diam.

8. Peronospora infestans, Mont. Magnified 350 diam.

\section{PLATE III.}

1. Section of leaf of Pinus austriaca, with Pestalozzia —_. Magnified 20 diam. The leaves are probably dying from some other fungus.

1a. Spores of same, magnified 85 diam.

2. Podosphæra kunzei (?) Lev. On cultivated cherry leaves; magnified 75 diam.

2a. Sporangium of same.

2b. Macrosporium-like or capnodium-like bodies on appendages.

2c. Appendage having moniliform divisions.

2d. Similar to c. Found mostly on mycelium.

3. Sphærotheca castagnei (?) Lev. On Erechtites hieracifolus; magnified 75 diam.

4. Sporangia of same.

5. Rhytisma acerinum, Fr. On leaf of Acer dasycarpum; natural size.

6. Vertical section of same. c. Asci with young spores.

7. Plycinidia of an Erysiphe on Verbena urticifolia.

7f. Macrosporium-like forms found with latter.

PLATE IV.

1. Erysiphe, - On Aster puniceus.

2. Microsphæria extensa, C. \& P. On Quercus rubra; magnified 75 diam.

3. Appendage, magnified 300 diam.

4. Ruptured conceptacle of same; a. sporangia.

5. Triposporium-like bodies on same mycelium.

6. Phylactinia guttata, Lev. On Fraxinus viridis.

7, 8, 9, 10 \& 11. Microsphæria ravenelii, Berk. On Gleditchia triacanthos.

12. Macrosporium-like bodies, with Microsphæria fresii, Lev. On leaves of Syringa vulgaris.

\section{THE TREE IN WINTER.}

\section{PLATE I.}

1. Aesculus glabra, Willd. Buckeye.

2. Acer saccharinum, Wang. Sugar maple.

3. Acer dasycarpum, Ehrh. Soft maple. 


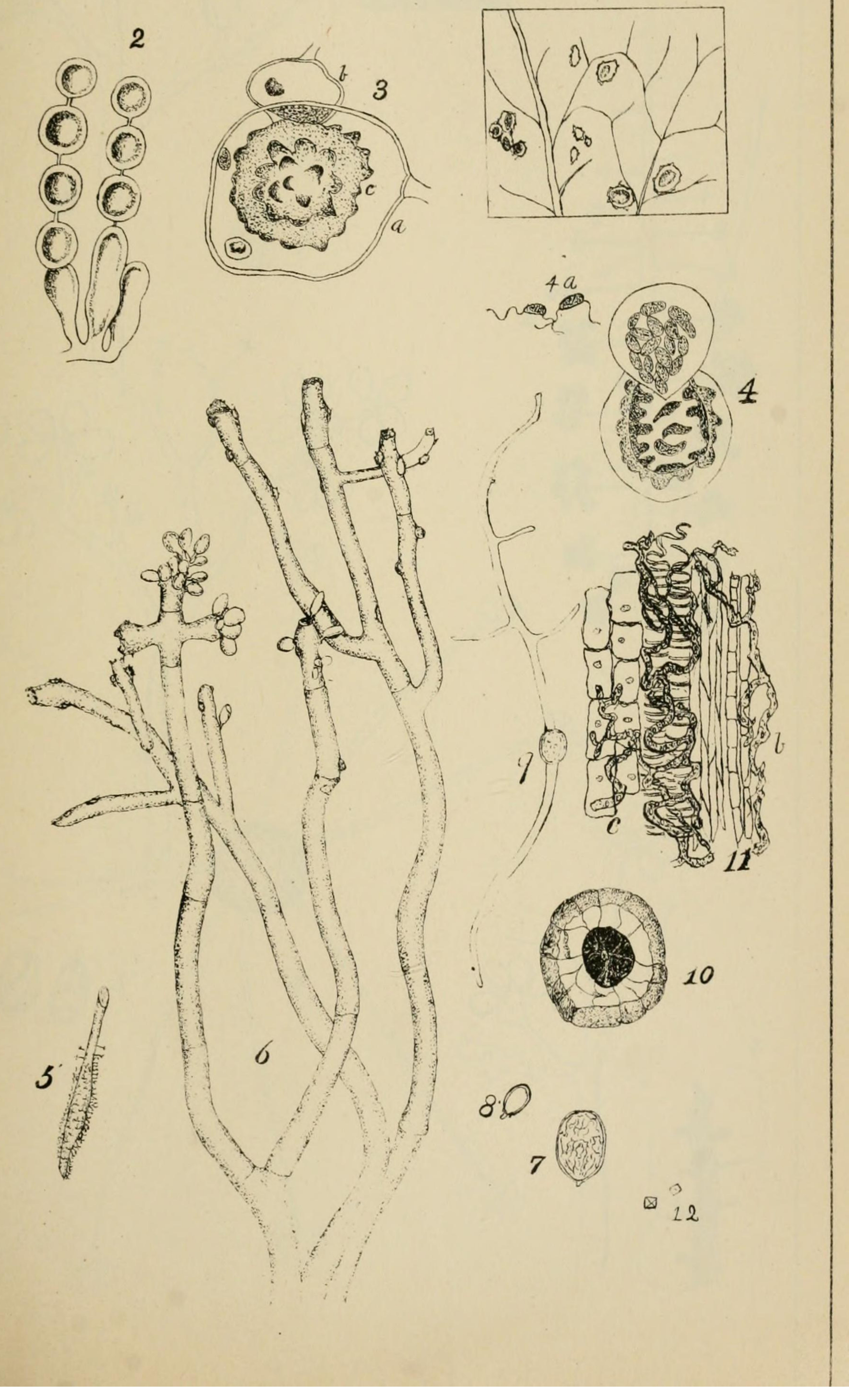


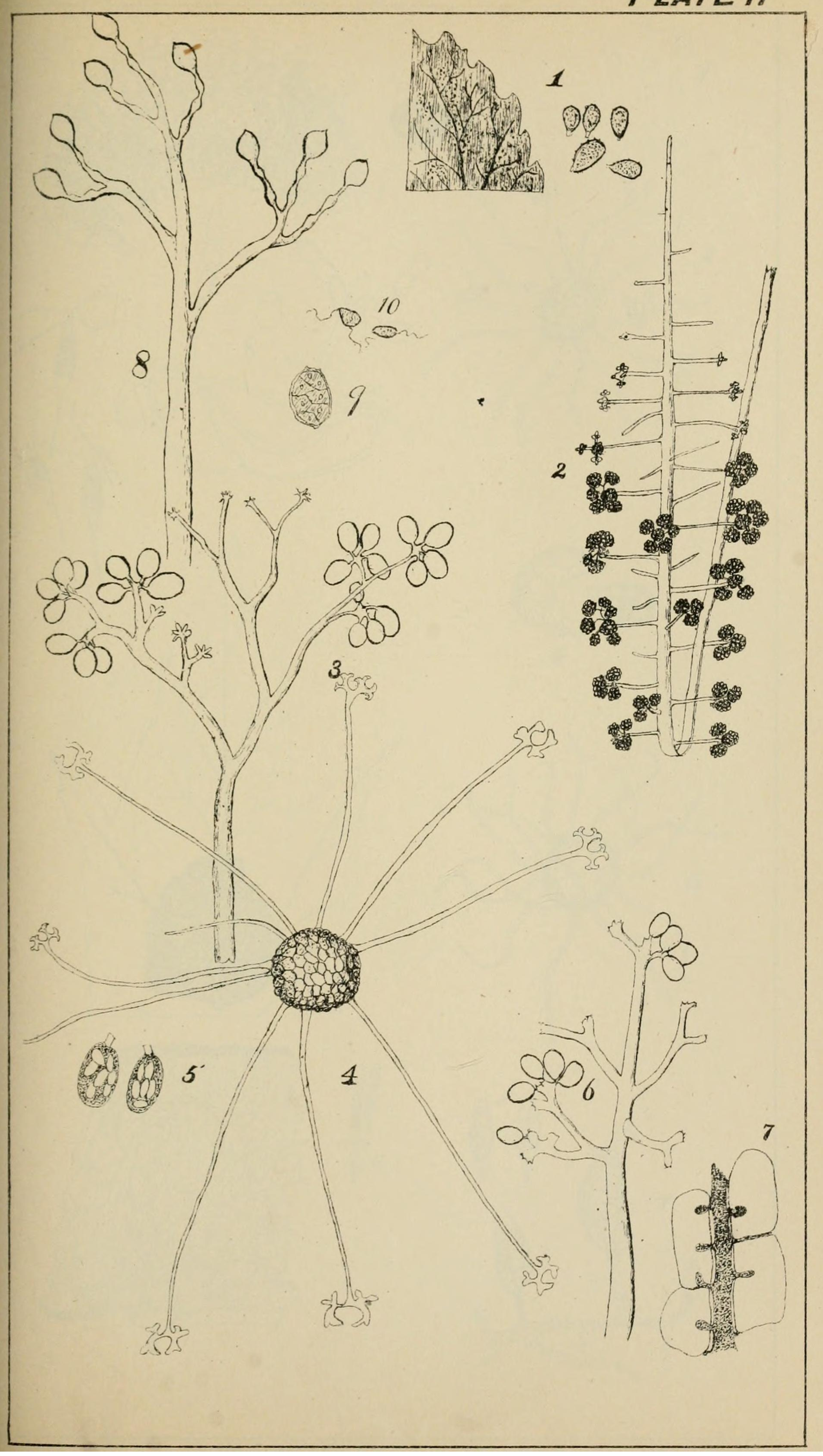





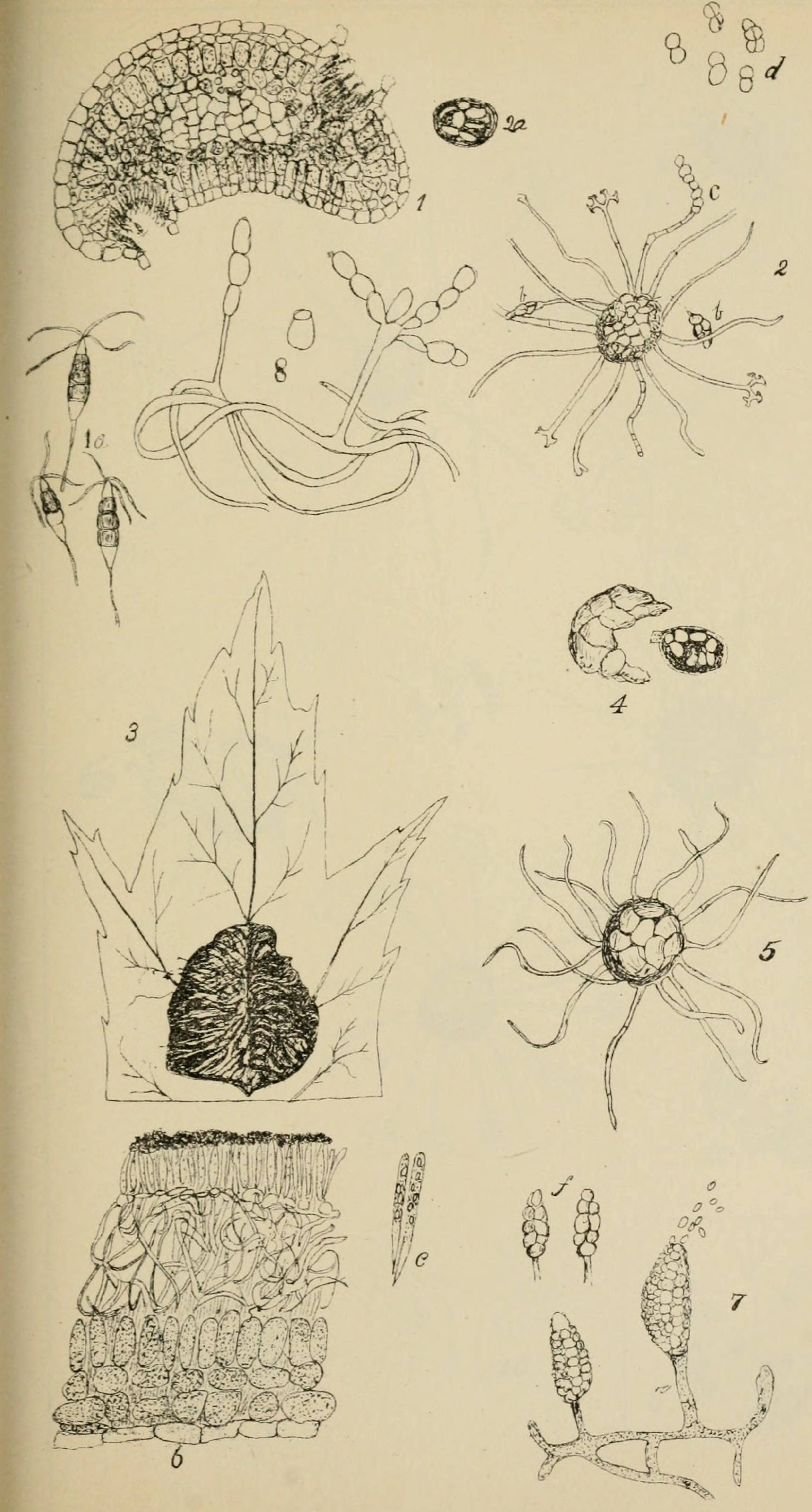





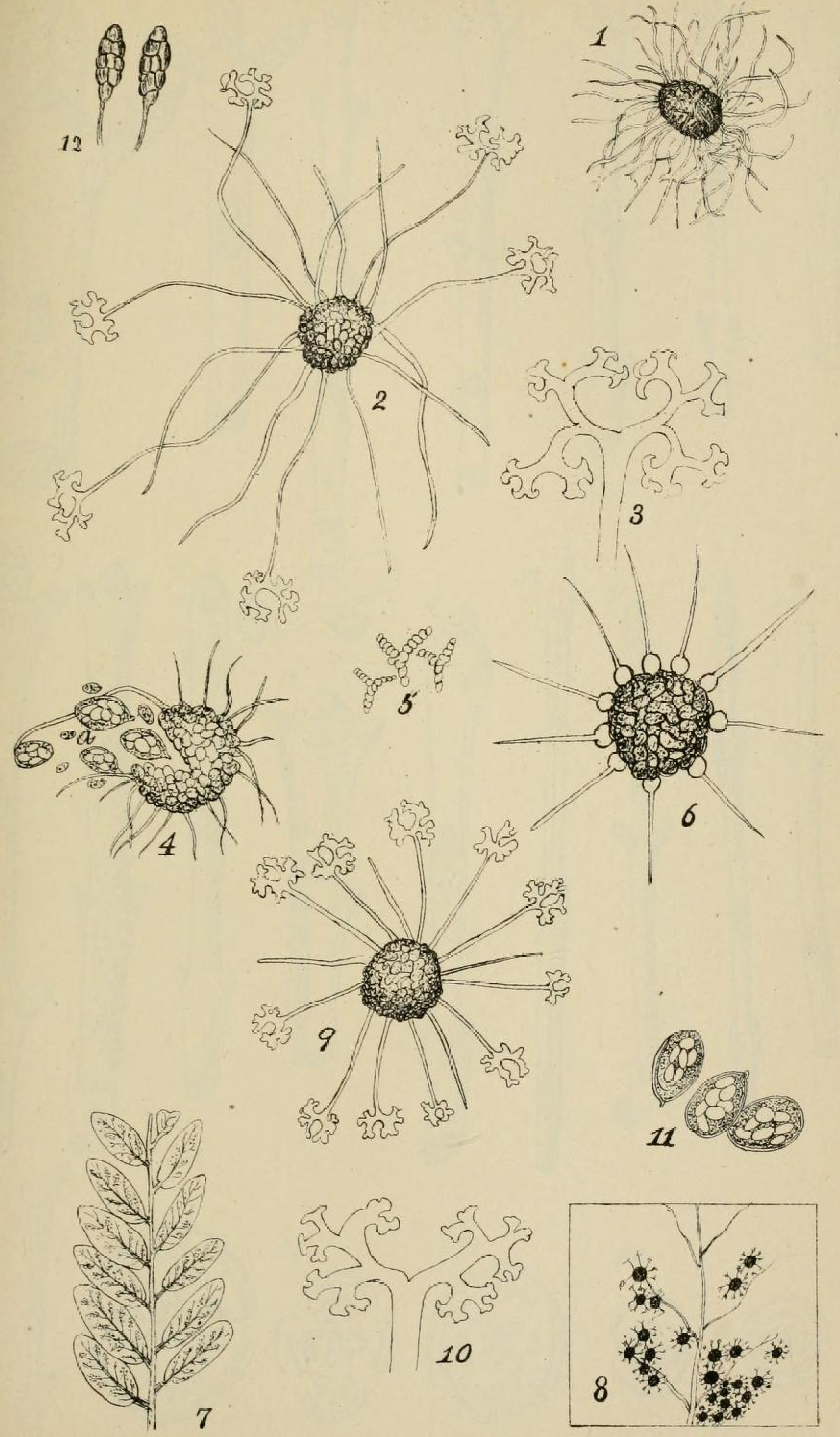




\section{E R R A T A.}

\section{B ULLETIN No. 1.}

Page 33, line 5, after Report, read 1853 and '4.

Page 34, insert Genus Poecilichthys, Ag. between numbers 1 and 2.

Page 38, second line, for 21-6 read $2 \frac{1}{6}$. Wherever, in this paper, two figures are separated by a hyphen, they should be written in the form of a common fraction.

Page 40, line 11, for Aphredodereus read Aphredoderus; under No. 40, for grumiens read grunniens.

Page 44, No. 71, for chrysochrous read chrysochloris; for J. N. read J. W.

Page 45, No. 74, for E. L. read F. L.

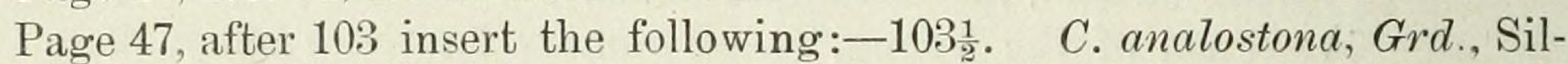
ver-fin. Everywhere abundant through Central Illinois. Occurs less commonly further north.

Page 52, Note 2, for der read den; for Archiev. read Archiv.

Note 3, for des read der; for Wein read Wien.

Page 53, 8th line, for M. Bary read DeBary.

Note 7, for der (Brandpilze) read die.

Page 54, for Peronosporice read Peronosporece.

Page 55, 8th line, for hauptoria read haustoria.

14th line, insert (12) after six, and add one to each of the three reference numerals following.

5 th line from bottom. omit (15).

$2 d$ line from bottom, insert (16) after Common.

Page 56, 10th line, 2d paragraph, instead of '75-6 read '74-5.

15th line from bottom, for pappillate read papillate.

11th line from bottom, for Poltactis read Polyactis.

Page 57, 7th line, for Peronosporice read Peronosporea.

21st line from bottom, insert European before vine.

Page 58, 8th line, for Peronosporice Peronosporece.

- $\quad 2 d$ line, $2 d$ paragraph, for 3 read 5.

7th and 8th lines, $2 d$ paragraph, for one to three read twelve to fifteen.

4th line from bottom, for bignouioides read bignonioides.

Page 68 , No. 40, reduce Acridium differentiale, etc., to a synonym, and insert above it $\mathrm{C}$. differentialis, Thos.

Page 72, Plate II, fig. 1, for Melanispora read Melampsora.

Page 73, Plate III, fig. 3, for 3 read 5.

Plate III, fig. 5 , for 5 read 3.

Plate III, fig. 7, for Plycinidia read Pycnidia.

Plate IV, fig. 12, for fresii read friesii. 